\title{
Update on the distribution of Peropteryx leucoptera Peters, 1867 (Mammalia, Chiroptera, Emballonuridae): First record for the state of Sergipe, northeastern Brazil
}

\author{
Jefferson S. Mikalauskas ${ }^{1 *}$, Patrício A. da Rocha ${ }^{2}$, Daniela Dias ${ }^{3}$ and Adriano L. Peracchi ${ }^{1}$ \\ 1 Graduate Program in Animal Biology, Mammalogy Laboratory, Universidade Federal Rural do Rio de Janeiro, BR 465, Km 7. CEP 23890-000, \\ Seropédica, RJ, Brazil. \\ 2 Graduate Program in Zoology, Departament of Systematics and Ecology,Universidade Federal da Paraíba, Cidade Universitária, s/n, Castelo \\ Branco. CEP 58051-900, João Pessoa, PB, Brazil. \\ 3 Foundation Oswaldo Cruz, Laboratory of Biology and Parasitology of Wild Mammals Reservoirs, Avenida Brasil, 4365. CEP 21040-900, \\ Manguinhos, RJ, Brazil. \\ * Corresponding author. E-mail: jsimanas@hotmail.com
}

\begin{abstract}
Three female specimens of Peropteryx leucoptera were collected in the Refúgio da Vida Silvestre Mata do Junco, a fragment of Atlantic Forest located in the state of Sergipe, northeastern Brazil. These specimens represent the first record of the species for Sergipe, increasing to 44 the number of bat species recorded in this state. A summary of locality records for $P$. leucoptera indicates a disjunct distributional pattern for this species, with the majority of the records concentrated in the northern South America and a separate population in the Atlantic Forest of northeastern Brazil.
\end{abstract}

The doglike bats of the genus Peropteryx Peters, 1867 are small to medium-sized emballonurines (head and body 45-55 mm; forearm 38-54 mm), whose the distribution is restricted to the Neotropics (Lim et al. 2010; McDonough et al. 2011; Suarez-Castro et al. 2012). They can be further recognized by the following set of characters: dorsal pelage ranging from dark buffy brown to blackish brown; underparts paler than dorsum; wing sac small, located near the anterior border of the antebrachial membrane, and opening distally; wing membranes (plagiopatagium) attached to the leg at the distal end of the tibia; skull with expanded rostrum, distinct angle between rostrum and forehead, relatively short postorbital processes, and undivided basisphenoid pit (no median septum); and spicule-like anterior upper premolar (Jones and Hood 1993; Hood and Gardner 2008). These bats also present sexual dimorphism in size, with females being larger than males (Hood and Gardner 2008), and are insectivorous, feeding preferentially on small beetles and flies (Bradbury and Vehrencamp 1976; Reis and Peracchi 1987).

Currently, five species of Peropteryx are recognized (Lim et al. 2010): P. kappleri Peters, 1867; P. leucoptera Peters, 1867; P. macrotis (Wagner, 1843), P. trinitatis Miller, 1899, and P. pallidoptera (Lim, Engstrom, Reid, Simmons, Voss \& Fleck, 2010). All these species occur in Brazil (Peracchi et al. 2011; Castro et al. 2012). Peropteryx leucoptera was originally described from a specimen collected in Suriname. Subsequently, this species was classified in its own subgenus Peronymus (Peters, 1868), which was later recognized as a genus (Miller 1907; Sanborn 1937; Corbet and Hill 1991). However, recent evidence shows that this taxon forms a monophyletic group with other Peropteryx (Lim et al. 2008), which supports the recognition of Peronymus as a junior synonym (Jones and Hood 1993; Simmons 2005; Hood and Gardner 2008; Lim et al. 2010). Peropteryx leucoptera is found in French Guiana, Guyana,
Suriname, Venezuela, Colombia, Peru, Brazil, and Ecuador (Hood and Gardner 2008; Lim et al. 2010; McDonough et al. 2010). In Brazil, this species occurs in the Amazon and Atlantic Forest biomes (Paglia et al. 2012), but few records are available, all from the states of Amazonas (Reis and Peracchi 1987; Sampaio et al. 2003), Pará (Vieira 1942, 1955; Bernard 1999; Bernard et al. 2001; Bernard and Fenton 2002; Marques-Aguiar et al. 2002), Pernambuco (Guerra 1980; Silva and Guerra 2000), and Paraíba (Feijó and Langguth 2011).

During a bat survey at the Refúgio da Vida Silvestre Mata do Junco (RVS-Mata do Junco) $\left(10^{\circ} 32^{\prime} \mathrm{S}, 37^{\circ} 03^{\prime}\right.$ W), a 894 ha state reserve located in the municipality of Capela, state of Sergipe, northeastern Brazil (Figure 1), three adult $P$. leucoptera were collected (license number: 2009.05.0603/00105-03). These bats were caught during the day, in their shelter, using hand nets. Mata do Junco is an area of open rainforest, with numerous tree fall gaps and surrounded by an anthropogenic matrix that includes sugar cane (Saccharum spp.) plantations.

The specimens of $P$. leucoptera are preserved in $70^{\circ}$ alcohol, with skulls removed, and were deposited in the Adriano Lúcio Peracchi Collection, at the Instituto de Biologia of the Universidade Federal Rural do Rio de Janeiro, under the numbers ALP 9730, 9731, and 9732. The specimens were identified according to the descriptions of Hood and Gardner (2008) and Lim et al. (2010). External and cranial measurements were obtained using callipers ( $0.02 \mathrm{~mm}$ precision) following the criteria described by Taddei et al. (1998).

The specimens examined present measurements within or very close to the variation reported for $P$. leucoptera (Table 1) and have translucent white dactylopatagium, but dark brown propatagium and plagiopatagium. Their ears are connected by a low band of skin across the forehead, and pterygoid pits are large and deep (Figure 2). This 
TABLE 1. Selected measurements of Peropteryx leucoptera from Refúgio da Vida Silvestre Mata do Junco, Sergipe, northeastern Brazil ${ }^{1}$, French Guiana ${ }^{2}$, Ecuador ${ }^{3}$, and Colombia ${ }^{4}$.

\begin{tabular}{|c|c|c|c|c|c|c|}
\hline & \multicolumn{3}{|c|}{ Present study ${ }^{1}$} & \multirow{2}{*}{$\begin{array}{c}\text { Lim et al. }(2010)^{2} \\
\text { Males }\end{array}$} & \multirow{2}{*}{$\begin{array}{c}\begin{array}{c}\text { McDonough et al. } \\
(2011)^{3}\end{array} \\
\text { Females }\end{array}$} & \multirow{2}{*}{$\begin{array}{c}\begin{array}{c}\text { Suaréz-Castro et al. } \\
(2012)^{4}\end{array} \\
\text { Males }\end{array}$} \\
\hline Sex & & Females & & & & \\
\hline Variables & ALP 9730 & ALP 9731 & ALP 9732 & & & \\
\hline Weight & 8.40 & 8.20 & 9.00 & $4.00-8.50$ & $5.50-8.50$ & - \\
\hline Tail length & 13.41 & 14.41 & 14.80 & $5.00-17.00$ & $12.00-17.00$ & $11.00-17.00$ \\
\hline Hind foot length & 7.52 & 6.70 & 8.48 & $7.00-10.00$ & $7.00-10.00$ & $7.00-9.00$ \\
\hline Ear length & 17.59 & 14.49 & 14.25 & $13.00-20.00$ & $15.00-18.50$ & $13.00-18.00$ \\
\hline Forearm length & 42.88 & 43.50 & 44.10 & $41.00-46.00$ & $42.00-45.00$ & $39.90-44.30$ \\
\hline Greatest skull length & 15.70 & 15.46 & 15.74 & $14.90-15.16$ & 15.80 & $15.10-16.10$ \\
\hline Condyloincisive length & 14.88 & 14.20 & 14.72 & $13.90-14.10$ & 14.80 & $13.80-14.70$ \\
\hline Upper toothrow length & 6.24 & 6.42 & 6.36 & $6.10-6.20$ & 6.50 & $6.30-6.60$ \\
\hline Breadth across upper canines & 4.28 & 4.26 & 4.18 & - & - & - \\
\hline Postorbital breadth & 3.26 & 3.62 & 3.28 & $3.10-3.30$ & 3.40 & $3.30-3.60$ \\
\hline Breadth across upper molars & 7.24 & 7.12 & 7.24 & $6.70-7.00$ & 7.40 & $6.90-7.50$ \\
\hline Braincase breadth & 7.30 & 7.46 & 7.32 & $7.00-7.30$ & 7.10 & $6.80-7.40$ \\
\hline Zygomatic breadth & 9.92 & 9.98 & 9.52 & $9.30-9.60$ & 10.20 & $9.50-10.10$ \\
\hline Mastoid breadth & 8.14 & 8.06 & 8.18 & $7.60-8.00$ & 7.90 & $7.70-8.00$ \\
\hline Mandible length & 11.26 & 11.14 & 11.24 & - & - & - \\
\hline Lower toothrow length & 6.56 & 6.40 & 6.56 & - & - & - \\
\hline \multicolumn{7}{|c|}{${ }^{2} \mathrm{~N}=14$ males and 7 females (external measurements); 4 males (cranial measurements) } \\
\hline \multicolumn{7}{|c|}{${ }^{3} \mathrm{~N}=9$ females (external measurements); 1 female (cranial measurements) } \\
\hline \multicolumn{7}{|c|}{${ }^{4} \mathrm{~N}=3$ males and 2 females (external measurements); 2 males and 1 female (cranial measurements) } \\
\hline
\end{tabular}

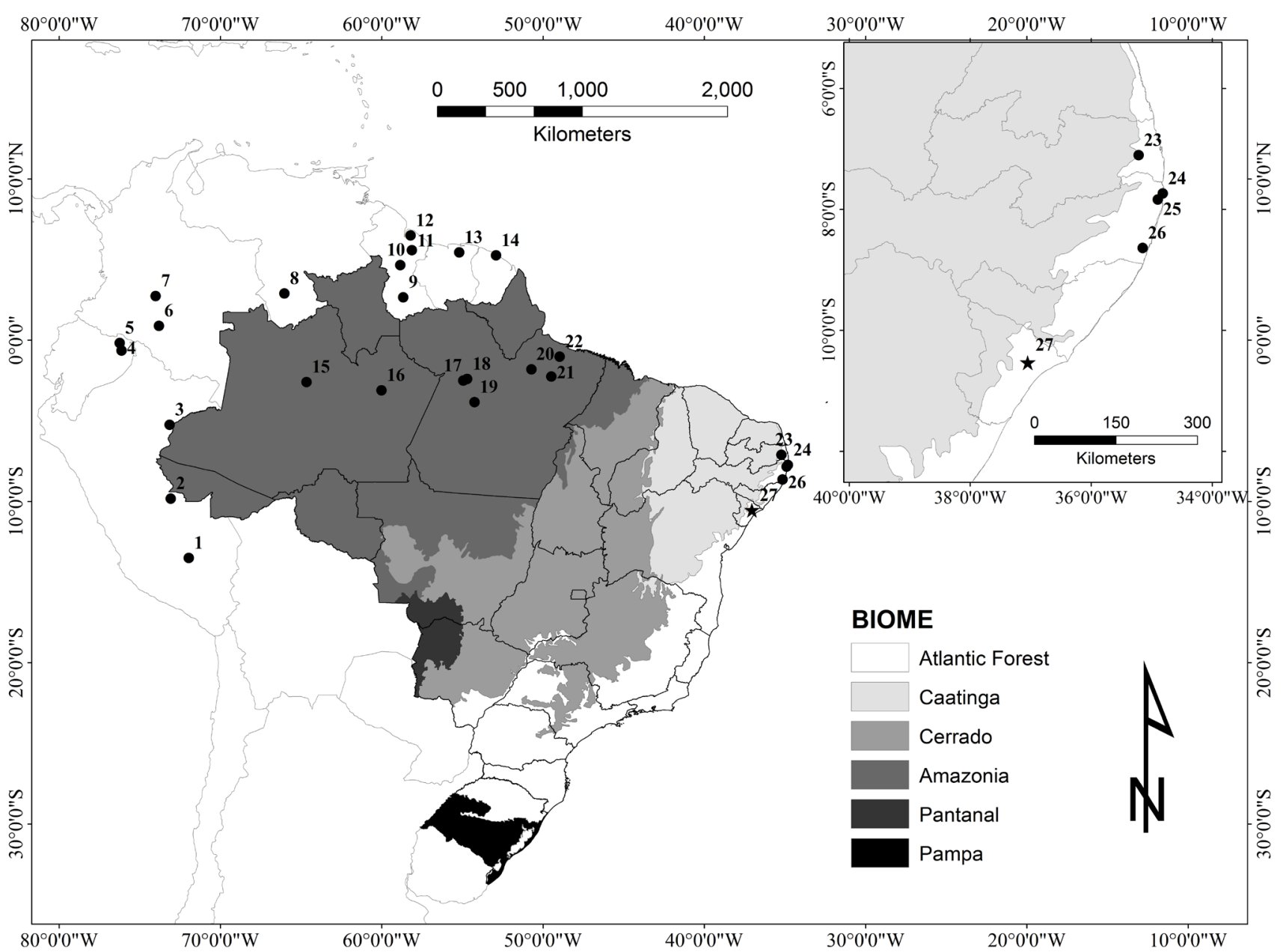

FIGURE 1. Geographic distribution of Peropteryx leucoptera and the new records (star) in the Refúgio da Vida Silvestre Mata do Junco, in the state of Sergipe, northeastern Brazil. For numbers of localities, see Table 2. 
combination of morphological characters is diagnostic for P. leucoptera (Hood and Gardner 2008; Lim et al. 2010). The recently described $P$. pallidoptera, recorded in Brazil based on a female collected in the state of Pará (Castro et al. 2012), also has pale or white wings beyond the forearm. However, in P. pallidoptera the propatagium and plagiopatagium are also translucent. Furthermore, this species has ears separated on the forehead and a skull with shallow pterygoid pits separated by a mesopterygoid extension and positioned anterolaterally to the basisphenoid pit (Lim et al. 2010).

Peropteryx leucoptera inhabits mainly primary and secondary rainforests (Simmons and Voss 1998; McDonough et al. 2011), but can also be found in dry open formations adjacent to riparian forests, agricultural areas, and pastures (Suaréz-Castro et al. 2012). Most available records were assigned based on individuals captured in roosts (e.g., hollow trees, cavities, under tree roots on the banks of rivers, under fallen tree trunks, dark spaces under tree leaves), although ground-level mist-nets have also been useful for capturing this species (Brosset and Charles-Dominique 1990; Simmons and Voss 1998; McDonough et al. 2011). Our specimens, three lactating females, two of which carrying young, were all collected inside a hollow tree (Eschweilera $\mathrm{sp}$ ). This reinforces the importance of sampling bat refuges, especially considering that emballonurids are difficult to be captured in mist-nets set in the understory (Simmons and Voss 1998).

The locality records available for P. leucoptera (Table 2 and Figure 1) indicate a disjunct pattern of geographic distribution for this species, with populations located in the northern South America and in the Atlantic Forest of northeastern Brazil. These populations seem to be morphologically similar, based on the mensural data analyzed here, but larger samples and diverse data sets should be considered in further taxonomic assessments.

The specimens collected here represent the first record of $P$. leucoptera for the state of Sergipe, where 43 species of bats have been recorded (Mikalauskas 2005; Feijó and Nunes 2010; Rocha et al., 2010, 2011a, 2011b; Mikalauskas et al. 2011; Brito and Bocchiglieri 2012; Leal et al. 2013). This record indicates the need for further sampling efforts in this region, in order to obtain a better understanding of the diversity, distribution patterns, and natural history of the bats, as well as their functional roles in the local ecosystems.

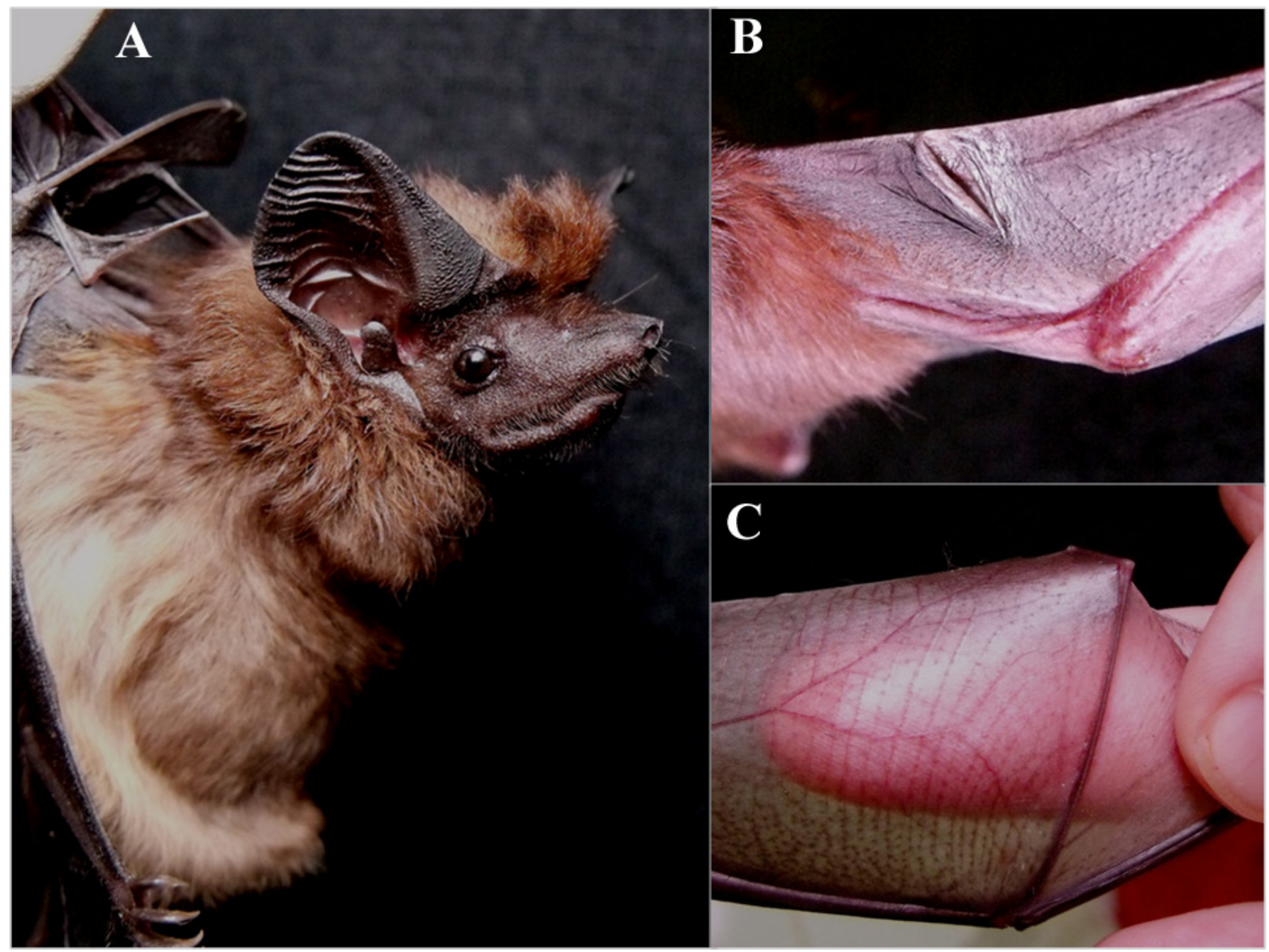

FIGURE 2. Live view of an adult female P. leucoptera collected at Refúgio da Vida Silvestre Mata do Junco, municipality of Capela, state of Sergipe, northeastern Brazil (A) (Photo by P. A. da Rocha), with details of the glandular pouch on propatagium (B) and white transparent wing membranes (C). 
TABLE 2. Locality records for Peropteryx leucoptera in Brazil and in other South American countries. The code numbers refer to the points shown in Figure 1.

\begin{tabular}{|c|c|c|c|c|}
\hline COUNTRY/ POINT & \multicolumn{2}{|c|}{ COORDINATES } & LOCALITY & \multirow[t]{2}{*}{ REFERENCE } \\
\hline \multicolumn{4}{|l|}{ PERU } & \\
\hline 1 & $13^{\circ} 30^{\prime} \mathrm{S}$ & $71^{\circ} 58^{\prime} \mathrm{W}$ & Madre de Dios- Cusco & Solari et al. (2006) \\
\hline 2 & $9^{\circ} 49^{\prime} \mathrm{S}$ & $73^{\circ} 5^{\prime} \mathrm{W}$ & $\begin{array}{l}\text { Ucayali, Tushemo(type locality of Peronymus } \\
\text { cyclops } 0 \text {. Thomas) }\end{array}$ & Thomas (1924) \\
\hline 3 & $5^{\circ} 14^{\prime} \mathrm{S}$ & $73^{\circ} 9^{\prime} \mathrm{W}$ & Loreto- Nuevo San Juan & Lim et al. (2010) \\
\hline \multicolumn{5}{|l|}{ ECUADOR } \\
\hline 4 & $0^{\circ} 38^{\prime} \mathrm{S}$ & $76^{\circ} 8^{\prime} \mathrm{W}$ & $\begin{array}{l}\text { Orellana -Province Tiputini Biodiversity } \\
\text { Station }\end{array}$ & Rex et al. (2008) \\
\hline 5 & $0^{\circ} 10^{\prime} \mathrm{S}$ & $76^{\circ} 15^{\prime} \mathrm{W}$ & Suriname & McDonough et al. (2011) \\
\hline \multicolumn{5}{|l|}{ COLOMBIA } \\
\hline 6 & $0^{\circ} 54^{\prime} \mathrm{N}$ & $73^{\circ} 49^{\prime} \mathrm{W}$ & Caquetá & Marin-Vasquez and Aguilar-González (2005) \\
\hline 7 & $2^{\circ} 45^{\prime} \mathrm{N}$ & $74^{\circ} 1^{\prime} \mathrm{W}$ & Meta - Campamento Chamusa & Lemke et al. (1982) \\
\hline \multicolumn{5}{|l|}{ VENEZUELA } \\
\hline 8 & $2^{\circ} 54^{\prime} \mathrm{N}$ & $66^{\circ} 2^{\prime} \mathrm{W}$ & Rio Casiquiare & GBIF - coletados por Olalla AMNH 78419 \\
\hline \multicolumn{5}{|l|}{ GUYANA } \\
\hline 9 & $2^{\circ} 40^{\prime} \mathrm{N}$ & $58^{\circ} 40^{\prime} \mathrm{W}$ & Upper Essequibo-Upper Takutu & Lim et al. (2010) \\
\hline 10 & $4^{\circ} 40^{\prime} \mathrm{N}$ & $58^{\circ} 51^{\prime} \mathrm{W}$ & $\begin{array}{l}\text { Potaro-Siparuni- Iwokrama Forest Field } \\
\text { Station }\end{array}$ & Lim et al. (2010); Lim and Engstrom (2001) \\
\hline 11 & $5^{\circ} 35^{\prime} \mathrm{N}$ & $58^{\circ} 8^{\prime} \mathrm{W}$ & Upper Demerara-Berbice-Bada Creek & Lim et al. (1999) \\
\hline 12 & $6^{\circ} 30^{\prime} \mathrm{N}$ & $58^{\circ} 13^{\prime} \mathrm{W}$ & Demerara-Mahaica-Ceiba Biological Center & Lim et al. (2010) \\
\hline \multicolumn{5}{|l|}{ SURINAM } \\
\hline 13 & $5^{\circ} 27^{\prime} \mathrm{N}$ & $55^{\circ} 12^{\prime} \mathrm{W}$ & Zanderij & Genoways et al. (1981) \\
\hline \multicolumn{5}{|l|}{ FRENCH GUIANA } \\
\hline 14 & $5^{\circ} 16^{\prime} \mathrm{N}$ & $52^{\circ} 55^{\prime} \mathrm{W}$ & Paracou & Simmons and Voss (1998) \\
\hline \multicolumn{5}{|l|}{ BRAZIL } \\
\hline 15 & $2^{\circ} 35^{\prime} \mathrm{S}$ & $64^{\circ} 40^{\prime} \mathrm{W}$ & $\begin{array}{l}\text { Reserva de Desenvolvimento Sustentável } \\
\text { Amanã-AM }\end{array}$ & Ramos et al. (2010) \\
\hline 16 & $3^{\circ} 6^{\prime} \mathrm{S}$ & $60^{\circ} 1^{\prime} \mathrm{W}$ & Manaus-AM & Reis (1984); Sampaio et al. (2003); Bernard et al. (2001) \\
\hline 17 & $2^{\circ} 30^{\prime} \mathrm{S}$ & $54^{\circ} 57^{\prime} \mathrm{W}$ & Alter do Chão-PA & Bernard and Fenton (2002); Bernard (1999) \\
\hline 18 & $2^{\circ} 24^{\prime} \mathrm{S}$ & $54^{\circ} 42^{\prime} \mathrm{W}$ & Santarém-PA & Bernard et al. (2001) \\
\hline 19 & $3^{\circ} 50^{\prime} \mathrm{S}$ & $54^{\circ} 15^{\prime} \mathrm{W}$ & Parque Nacional da Amazônia-PA & Reis and Schubart (1979) \\
\hline 20 & $1^{\circ} 48^{\prime} \mathrm{S}$ & $50^{\circ} 43^{\prime} \mathrm{W}$ & $\begin{array}{l}\text { Estação Científica Ferreira Penna- município } \\
\text { de Melgaço- PA }\end{array}$ & Marques-Aguiar et al. (2003) \\
\hline 21 & $2^{\circ} 15^{\prime} \mathrm{S}$ & $49^{\circ} 9^{\prime} \mathrm{W}$ & Cometá-PA & Sanborn (1937) \\
\hline 22 & $1^{\circ} 1^{\prime} \mathrm{S}$ & $48^{\circ} 58^{\prime} \mathrm{W}$ & Cachoeira, Ilha de Marajó-PA & Vieira (1942); Vieira (1955) \\
\hline 23 & $7^{\circ} 6^{\prime} \mathrm{S}$ & $35^{\circ} 13^{\prime} \mathrm{W}$ & Sapé-PB & Feijó and Langguth (2011) \\
\hline 24 & $7^{\circ} 44^{\prime} \mathrm{S}$ & $34^{\circ} 49^{\prime} \mathrm{W}$ & Itamaracá-PE & Monteiro da Cruz et al. (2002) \\
\hline 25 & $7^{\circ} 50^{\prime} \mathrm{S}$ & $34^{\circ} 54^{\prime} \mathrm{W}$ & $\begin{array}{l}\text { Refúgio Ecológico Charles Darwin / } \\
\text { Iguarassu-PE }\end{array}$ & Silva and Guerra (2000) \\
\hline 26 & $8^{\circ} 38^{\prime} \mathrm{S}$ & $35^{\circ} 9^{\prime} \mathrm{W}$ & $\begin{array}{l}\text { Estação Experimental de Saltinho-Rio } \\
\text { Formoso-PE }\end{array}$ & Guerra (1980) \\
\hline 27 & $10^{\circ} 32^{\prime} \mathrm{S}$ & $37^{\circ} 3^{\prime} \mathrm{W}$ & RVS Mata do Junco- Capela & This study \\
\hline
\end{tabular}

AcKnowledgments: We are thankful to CAPES and CNPq for graduate scholarships to PAR and JSM, respectively; to the Secretary of Environment and Water Resources (SEMARH) for logistical support; to Marcelo José Silva ("Guigó"), for invaluable help during field work; and to Stephen Ferrari and Sidclay Calaças Dias for revision of the text.

\section{Literature Cited}

Bernard, E. 1999. Notes on a colony of Peropteryx leucoptera (Emballonuridae) in Brazil. Bat Research News 40(2): 37-38.

Bernard, E., A.L.K.M. Albernaz and W.E. Magnusson. 2001. Bat species composition in three localities in the Amazon basin. Studies on Neotropical Fauna and Environment 36(11): 177-184.

Bernard, E. and M.B. Fenton. 2002. Species diversity of bats (Chiroptera: Mammalia) in forest fragments, primary forests and savannas in Central Amazonia, Brazil. Canadian Journal of Zoology 80(9): 11241140.

Bradbury, J.W. and S.L. Vehrencamp. 1976. Social organization and foraging in emballonurid bats. I. Field studies. Behavioral Ecology and Sociobiology 1: 337-381.

Brito, D.V. and A. Bocchiglieri. 2012. Comunidade de morcegos (Mammalia, Chiroptera) no Refúgio de Vida Silvestre Mata do Junco, Sergipe, nordeste do Brasil. Biota Neotropica 12(3): 1-8.
Brosset, A. and P. Charles-Dominique. 1990. The bats from French Guiana: a taxonomic, faunistic and ecological approach. Mammalia 54(4): 509-560.

Castro, I.J., E.R. Santos, A.C.M. Martins, D. Dias and A.L. Peracchi. 2012. First record of the pale winged dog like bat Peropteryx pallidoptera (Chiroptera: Emballonuridae) for Brazil. Mammalia 76(4): 451-453.

Corbet, G.B. and J.E. Hill. 1991. A world list of mammalian species. Third edition. London: Natural History Museum Publications and Oxford University Press, 243 pp.

Feijó, J.A. and H.L. Nunes. 2010. Mammalia, Chiroptera, Phyllostomidae, Artibeus planirostris (Spix, 1823) and Trachops cirrhosus (Spix, 1823): First record for the state of Sergipe, northeastern Brazil. Check List 6(1): 15-16.

Feijó, J.A. and A. Langguth. 2011. Lista de Quirópteros da Paraíba, Brasil com 25 novos registros. Chiroptera Neotropical 17(2): 1055-1062.

GBIF Annual Report. 2012. Global Biodiversity Information Facility. Accessible at http:// www.gbif.org/orc/doc_id=5304|. Captured on 05 January 2013.

Genoways, H.H., S.L. Williams and J.A. Groen. 1981. Results of the Alcoa Foundation-Suriname Expeditions. V. Noteworthy records of Surinamese mammals. Annals of the Carnegie Museum 50: 319-32.

Guerra, D.Q. 1980. Peropteryx (Peronymus) leucopterus Peters, 1867 no 
nordeste do Brasil (Chiroptera - Emballonuridae). Revista Nordestina de Biologia 3: 137-139.

Hood, C. and A.L. Gardner. 2008. Family Emballonuridae Gervais, 1856; pp. 188-207, in: A.L. Gardner (ed.). Mammals of South America Volume I: Marsupials, Xenarthrans, Shrews, and Bats. Chicago: The University of Chicago Press.

Jones Jr., J.K. and C.S. Hood. 1993. Synopsis of South American bats of the family Emballonuridae. Occasional Papers, The Museum, Texas Tech University 155: 1-32.

Leal, E.S.B., S.M. Azevêdo Jr., F.V.P. Vila Nova, D.Q. Guerra and W.R. Telino-Jr. 2013. Updated compilation of bat species (Chiroptera) for the Brazilian state of Sergipe, including new records. Chiroptera Neotropical 19(1): 1163-1178.

Lemke, T.O., A. Cadena, R.H. Pine and J. Hernández-Camacho. 1982. Notes on opossums, bats, and rodents new to the fauna of Colombia. Mammalia 46: 225-34.

Lim, B.K., M.D. Engstrom, R.M. Timm, R.P. Anderson and L.C. Watson. 1999. First records of 10 bat species in Guyana and comments on diversity of bats in Iwokrama Forest. Acta Chiropterologica 1: 179-190.

Lim, B.K., M.D. Engstrom. 2001. Species diversity of bats (Mammalia: Chiroptera) in Iwokrama Forest, Guyana, and the Guianan subregion: implications for conservation. Biodiversity and Conservation 10: 613-657.

Lim, B.K., M.D. Engstrom, J.W. Bickham and J.C. Patton. 2008. Molecular phylogeny of New World sheath-tailed bats (Emballonuridae: Diclidurini) based on loci from the four genetic transmission systems in mammals. Biological Journal of the Linnean Society 93: 189-209.

Lim, B.K., M.D. Engstrom, F.A. Reid, N.B. Simmons, R.S. Voss and D.W. Fleck. 2010. New Species of Peropteryx (Chiroptera: Emballonuridae) from Western Amazonia with Comments on Phylogenetic Relationships within the Genus. American Museum Novitates 3686: 1-20.

Marin-Vasquez A. and A.V. Aguilar-González. 2005. Murciélagos del departamento de Caquetá-Colombia. Biota Colombiana 6: 211-218.

Marques-Aguiar, S.A., C.C.S. Melo, G.F.S. Aguiar and J.A.L. Queiróz. 2002. Levantamento preliminar da mastofauna da região de Anajás-Muaná, Ilha de Marajó, Pará, Brasil. Revista Brasileira de Zoologia 19(3): 841854.

Marques-Aguiar, S.A., M.V. Aguila, G.F.S. Aguiar, N. Saldanha, J. Silva-Junior and M.M.B. Rocha. 2003. Caracterização e perspectivas de estudo dos quirópteros da Estação Científica Ferreira Penna- município de Melgaço-PA. Ideias e Debates 6: 1-3.

McDonough, M.M., B.K. Lim, A.W. Ferguson, C.M. Brown, S.F. Burneo and A.K. Loren. 2011. Mammalia, Chiroptera, Emballonuridae, Peropteryx leucoptera Peters, 1867 and Peropteryx pallidoptera Lim, Engstrom, Reid, Simmons, Voss, and Fleck, 2010: distributional range extensions in Ecuador. Check List 6(4): 639-643.

Mikalauskas, J.S. 2005. Morcegos; pp. 93-103, in: C.M. Carvalho and J.C. Vilar (ed.). Parque Nacional Serra de Itabaiana - Levantamento da Biota. Aracaju: IBAMA, UFS. Biologia Geral e Experimental.

Mikalauskas, J.S., P.A. Rocha, D. Dias and A.L. Peracchi. 2011. Mammalia, Chiroptera, Vespertilionidae Rhogeessa hussoni Genoways \& Baker, 1996: first record for the state of Sergipe, Northeastern Brazil. Check List 7(6): 883-885.

Miller, G.S. 1907. The families and genera of bats. United States National Museum Bulletin 57: 1-282.

Monteiro da Cruz, M.A.O., M.C.C. Cabral, L.A.M. Silva and M.L.C.B. Campelo. 2002. Diversidade da Mastofauna no Estado de Pernambuco; pp. 557-559 In M. Tabarelli and J.M.C. Silva (ed.). Diagnostico da Biodiversidade de Pernambuco. Volume 2. Recife: Secretaria de Ciências, Tecnologia e Meio Ambiente.

Paglia, A.P., G.A.B. da Fonseca, A.B. Rylands, G. Herrmann, L.M.S. Aguiar, A.G. Chiarello, Y.L.R. Leite, L.P Costa, S. Siciliano, M.C.M. Kierulff, S.L. Mendes, V. C. Tavares, R.A. Mittermeier and J.L. Patton. 2012. Lista anotada dos mamíferos do Brasil / Annotated checklist of Brazilian mammals. 2nd Edition. Occasional Papers in Conservation Biology, No. 6. Arlington: Conservation International.

Peracchi, A.L., I.P. Lima, N.R. Reis, M.R. Nogueira and H. Ortêncio Filho. 2011. Ordem Chiroptera; pp. 155-234, in: N.R. Reis, A.L. Peracchi, W.A. Pedro and I.P. Lima (ed.). Mamíferos do Brasil, 2 a ed. Londrina: Editora da Universidade Estadual de Londrina.
Ramos P.M.J., J.T. Marques and J.M. Palmeirim. 2010. Vertical stratification of bat assemblages in flooded and unflooded Amazonian forests. Current Zoology 56(4): 469-478.

Reis, N.R. 1984. Estrutura de comunidade de morcegos na região de Manaus, Amazonas. Revista Brasileira de Biologia 44: 247-54.

Reis, N.R. and A.L. Peracchi. 1987. Quirópteros da região de Manaus, Amazonas, Brasil (Mammalia, Chiroptera). Boletim do Museu Paraense Emílio Goeldi, Série Zoologia 39(20): 161-182.

Reis, N.R. and H.O.R. Schubart. 1979. Notas preliminares sobre os morcegos do Parque Nacional da Amazônia (Médio Tapajós). Acta Amazônica 9: 507-515.

Rex, K., D.H. Kelm, K. Wiesner, T.H. Kunz and C.C. Voigt. 2008. Species richness and structure of three Neotropical bat assemblages. Biological. Journal of the Linnean Society 94: 617-629.

Rocha, P.A., J.S. Mikalauskas, S.F. Gouveia, V.V.B. Silveira, and A.L. Peracchi. 2010. Morcegos (Mammalia, Chiroptera) capturados no Campus da Universidade Federal de Sergipe, com oito novos registros para o estado. Biota Neotropica 10(3): 183-188.

Rocha P.A., J.A. Feijó, J.S. Mikalauskas and S.F. Ferrari. 2011a. First records of mormoopid bats (Chiroptera, Mormoopidae) from the Brazilian Atlantic Forest. Mammalia 75(3): 295-299.

Rocha, P.A., J.A. Feijó, J. Ruiz-Esparza and S.F. Ferrari. 2011b. Uroderma magnirostrum Davis, 1968 (Chiroptera, Phyllostomidae): First record from the state of Sergipe, Northeastern Brazil. Check List 7(6): 886-888.

Sampaio, E.S., E.K.V. Kalko, E. Bernard, B. Rodriguez-Herrera and C.O. Handley, Jr. 2003. A biodiversity assessment of bats (Chiroptera) in a tropical lowland rainforest of Central Amazonia, including methodological and conservation considerations. Studies on Neotropical Fauna and Environment 38(1): 17-31.

Sanborn, C.C. 1937. American bats of the subfamily Emballonurinae. Field Museum of Natural History, Zoological Series 24: 321-354.

Silva, L.A.M. and D.Q. Guerra. 2000. Bats from a remnant of Atlantic forest in northeast Brazil. Chiroptera Neotropical 6(1-2): 125-126.

Simmons, N.B. 2005. Order Chiroptera; p. 312-529 In D.E. Wilson and D.M. Reeder (ed.). Mammal species of the world: a taxonomic and geografic reference. 3rd Edition. Baltimore: Johns Hopkins University Press.

Simmons, N.B. and R.S. Voss. 1998. The mammals of Paracou, French Guiana: a neotropical lowland rainforest fauna. Part I. Bats. Bulletin of the American Museum of Natural History 273: 1-219.

Solari, S.V., V. Pacheco, L. Luma, P.M. Velazco and B.D. Patterson. 2006. Mammals of the Manu Biosphere; pp. 13-23, in: B.D. Patterson, D.F. Stotz and S. Solari (ed.). Mammals and Birds of the Manu Biosphere Reserve, Peru. Fieldiana, Zoology, n. s., $N^{\circ} 10$.

Suaréz-Castro, A.F., H.E. Ramirez-Chaves, M.E. Rodriguez-Posada and J. Garcia. 2012. New records of Peropteryx leucoptera and first record of Peropteryx pallidoptera (Chiroptera-Emballonuridae) from Colombia. Mastozoología Neotropical 19(1): 165-171.

Taddei, V.A., C.A. Nobile and E. Morielle-Versute. 1998. Distribuição geográfica e análise morfométrica comparativa em Artibeus obscurus (Schinz, 1821) e Artibeus fimbriatus Gray, 1838 (Mammalia, Chiroptera, Phyllostomidae). Ensaios e Ciência 2(2): 71-127.

Thomas, O. 1924. On a collection of mammals made by Mr. Lathan Rutter in the Peruvian Amazonas. Annals and Magazine of Natural History 9(13): 530-538.

Vieira, C.O.C. 1942. Ensaio Monográfico sobre os Quirópteros do Brasil. Arquivos de Zoologia 3: 219-471.

Vieira, C.O.C. 1955. Lista remissiva dos mamíferos do Brasil. Arquivos de Zoologia do Estado de São Paulo 8: 341-474.

RECEIVED: September 2013

ACCEPTED: March 2014

Published online: May 2014

EDITORIAL RESPONSIBILITY: Marcelo R. Nogueira 